\title{
JAWABAN SOAL UTS 2018/2019 HAKI
}

\section{YENI SUSNTI}

165100114

Fakultas Komputer, 448757272

yenisusanti.student@umitra.ac.id

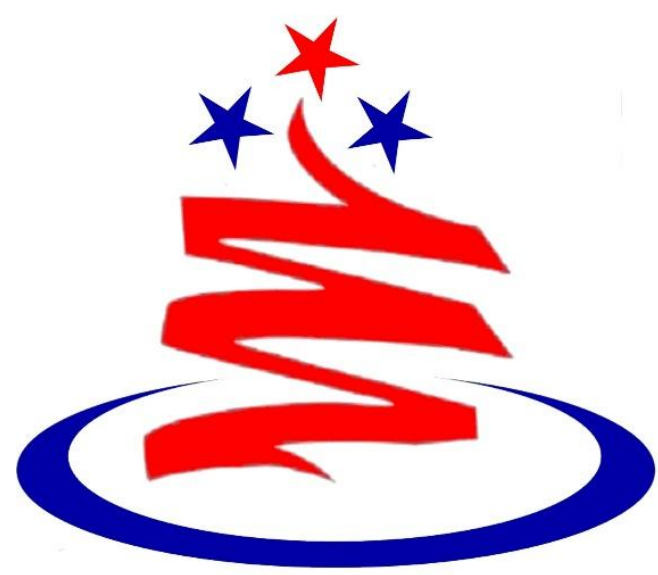

UnIVERSITAS mITRA InDONESIA 


\section{A. STUDI KASUS ( SK )}

Pertanyaan Type C :

paparkan dan jelaskan product knowledge (KS)/ produk tim anda (KP)

Jawaban :

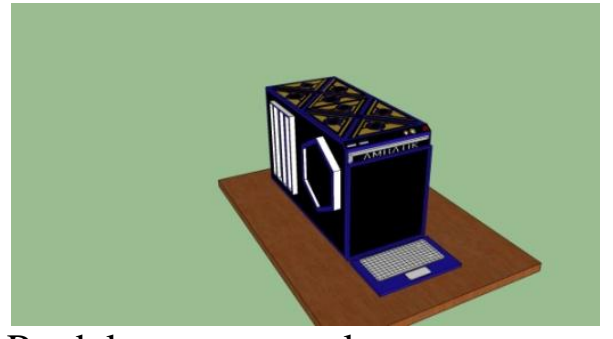

Produk yang akan saya jelaskan produk prangkat komputer yang bermark AMBATIK" Yang terdiri dari dua kata "amba" dan "tik", amba (luas), tik (titik), jadi Ambatik berarti titik luas dan dipatenkan oleh Penemuan AMBATIK ini dibuat oleh 5 pemuda pemudi Defsy. Dibuat dinegara indonesia pada provinsi Lampung tahun 2018.

Produk ini memiliki rahasia dagang Memiliki sistem operasi yang berbeda dengan komputer lainnya namanya adalah Max OS atau yang bisa disebut Maksimal Operating System.

Selain itu memiliki desain industri Komputer ini memiliki warna casing hitam yang dilapisi list warna biru, dibalut dengan desain batik batik dibagian atas dan samping CPU, dan memiliki khas tersendiri. Komputer ini berbentuk kotak memanjang, monitor serta CPU menyatu dengan PC. Monitor bisa dipisahkan dengan CPU. Jika dipisahkan bisa berfungsi sebagai tablet. Selain itu memiliki Spesifikasi komputerPC Processor Intel Core i7 $3770 \mathrm{~K}$ Motherbord : AMBATIK Sabertooth Defsy 887

VGA : Gigabyte BTX690

Ram : $32 \mathrm{~Gb}$

Hardisk : Western digital 1 Tb Caviar

SSD : OCZ Vector $256 \mathrm{~Gb}$

DVD Room : Bluray Combo SE-406 B

Cooler/kipas $\quad$ : Corsair H100i

PSU : SeaSonic P860

- Spesifikasi Monitor

Size

: $30^{\prime} \mathrm{TN}$

Panel

Resolution

1920x 1080/Full HD

Connectivity : D-

Sub/Dvi/HDMI/Headphone

Jack

Cable Included : : HDMI

Response Time : $1 \mathrm{Ms}$

Dan memiliki tata letak sircuitly Monitor didesain menempel dengan CPU.

OS (Operating System) Defsy yang bawaan dari PC AMBATIK.

\section{B. STUDI REFERENSI ( SP )}

Pertanyaan Jenis b :

Jelaskan pasal pasal pendukung didalam hak atas kekayaan intelektual

Jawaban : 
Pemerintah Republik Indonesia telah membuat undang-undang perlindungan tentang Hak Cipta dan Hak Atas Kekayaan Intelektual (HAKI) untuk melindungi hasil karya cipta seseorang seperti perangkat lunak atau program komputer. Undang-undang Hak Cipta yang berlaku saat ini adalah

Undang-Undang Hak Cipta No. 19

Tahun 2002 yang merupakan penyempurnaan dari Undang-Undang Hak Cipta No. 6 Tahun 1982, UndangUndang Hak Cipta No. 7 Thun 1987, dan Undang-Undang Hak Cipta No. 12 Tahun 1997.

Menurut Pasal 2 Ayat (2) UU Hak Cipta No. 19 Tahun 2002 menyatakan bahwa Pencipta atau Pemegang Hak Cipta atas sinematografi dan Program Komputer memiliki hak untuk memberikan izin atau melarang orang lain yang tanpa persetujuannya menyewakan Ciptaan tersebut untuk kepentingan yang bersifat komersil.

Ada beberapa hal yang perlu kita ketahui sebelu mengutip/mengkopi hasil karya orang lain. Menurut Pasal 15 UU Hak Cipta No. 19 Tahun 2002 menyatakan bahwa: "Dengan syarat bahwa sumbernya harus disebutkan atau dicantumkan, tidak dianggap sebagai pelanggaran Hak Cipta:

1. penggunaan Ciptaan pihak lain untuk kepentingan pendidikan, penelitian, penulisan karya ilmiah, penyusun laporan, penulisan kritik atau tinjauan suatu masalah dengan tidak merugikan kepentingan yang wajar dari Pencipta;
2. pengambilan Ciptaan pihak lain, baik seluruhnya maupun sebagian, guna keperluan pembelaan di dalam atau di luar negeri;

3. pengambilan Ciptaan pihak lain, baik seluruhnya maupun sebagian, guna keperluan

i) ceramah yang semata-mata untuk tujuan pendidikan dan ilmu pengetahuan, atau

ii) pertunjukan atau pementasan yang tidak dipungut bayaran dengan ketentuan tidak merugikan kepentingan yang wajar dari Pencipta;

1. perbanyakan suatu Ciptaan bidang ilmu pengetahuan, seni dan sastra dalam huruf braile guna keperluan tuna netra, kecuali jika Perbanyakan itu bersifat komersial;

2. perbanyakan suatu Ciptaan selain Program Komputer secara terbatas dengan cara atau alat apapun atau proses yang serupa oleh perpustakaan umum, lembaga ilmu pengetahuan atau pendidikan, dan pusat dokumentasi yang nonkomersial semata-mata untuk keperluan aktivitasnya;

3. perubahan yang dilakukan berdasarkan pertimbangan pelaksanaan teknis atas karya arsitektur, seperti Ciptaan bangunan;

4. pembuatan salinan cadangan suatu Program Komputer oleh Pemilik Program Komputer yang dilakukan semata-mata untuk digunakan sendiri." 
Berdasarkan ketentuan-ketentuan diatas maka tata cara mengutip atau mengkopi hasil karya orang lain antara lain sebagai berikut:

1. setiap pengambilan atau pengutipan Ciptaan pihak lain sebagian maupun seluruhnya harus mencatumakan sumbernya jika tujuan pengambilan tersebut untuk keperluan seperti yang disebutkan pada pasal $15 \mathrm{UU}$ Hak Cipta No. 19 Tahun 2002 di atas. Namun jika tujuannya untuk keperluan di luar yag ditentukan oleh pasal tersebut seperti komersialisasi atau mencari keuntungan, maka kita perlu mendapatkan persetujuan dari Pemegang Hak Cipta dengan ketentuan yang sudah diatur oleh undang-undang.

2. Pemilik suatu Program Komputer (bukan Pemegang Hak Cipta Program Komputer) dibolehkan membuat salinan Program Komputer yang dimilikinya tersebut untuk dijadikan cadangan, jika digunakan untuk keperluan sendiri, bukan untuk komersialisasi atau mencari keuntungan. Hal ini sudah diterapkan dalam pasal $15 \mathrm{UU}$ Hak Cipta No. 19 Tahun 2002 huruf $g$.

\section{STUDI PENALARAN ( SP )}

Pertanyaan Kategori 3: buatlah penjelasan secara detail produk BLACKBARRY dan beberapa bagian haki yang ikut serta didalamnya
Jawaban :

Blackberry dapat dibagi menjadi dua. Yang pertama, Blackberry sebagai merek produk dari sebuah produsen ponsel (sama halnya seperti Nokia, Sony Ericsson dan Motorola) yang dihasilkan oleh Research In Motion (RIM), perusahaan asal

Kanada. Pengertian kedua, Blackberry sebagai layanan yang disediakan oleh operator telekomunikasi. Dari sisi layanan, Blackberry adalah produk layanan yang dihasilkan operator telekomunikasi terdiri dari push email, chating dan browsing internet, sehingga dapat diakses secara cepat melalui telepon selular (ponsel). Dari tiga layanan itu, keistimewaan Blackberry terutama terletak pada layanan push mail. "Sederhananya dengan layanan ini pelanggan dapat menerima email secepat dan semudah menerima SMS (pesan singkat)," jelas Hery

BlackBerry adalah perangkat genggam nirkabel yang memiliki kemampuan layanan push e-mail, telepon seluler, sms, faksimili internet, menjelajah Internet, dan berbagai kemampuan nirkabel lainnya

SEJARAHNYA

RIM didirikan oleh seorang imigran Yunani di kota Waterloo, Kanada, oleh RIM (Research in Motion) perangkat komunikasi BlackBerry ini pertama kali dikenalkan pada tahun 1997. Sejak peluncurannya pada tahun 1999, 
BlackBerry telah berhasil meraup lebih dari 8 juta pelanggan di seluruh dunia.

Awalnya, BlackBerry ingin dinamakan POCKET LINK, dan hampir juga dinamakan STRAWBERRY karena mirip dengan buah strawberry, namun kandas karena terkesan lembek dan akhirnya perangkat komukasi ini dinamakan BlackBerry.

Di Indonesia sendiri, BlackBerry diperkenalkan pertama kali pada pertengahan bulan Desember 2004 oleh operator Indosat dan perusahaan Starhub. Perusahaan Starhub ini sebenernya adalah Rekan utama BlackBerry di Indonesia dan menjadi bagian dari layanan dalam segala hal teknis mengenal instalasi BlackBerry melalui operator Indosat. Indosat sendiri menyediakan layanan BlackBerry Internet Services dan BlackBerry Enterprise Server. Namun di tahun 2006, Indosat menangani sendiri kerjasama BlackBerry dengan produsen asal Canada, RIM (Research In Motion), untuk memasarkan BlackBerrynya. Selain Indosat, BlackBerry yang resmi saat ini dijual melalui operator XL, telkomsel, AXIS, dan lainya.

Kemunculan BlackBerry di Indonesia bisa dikatakan sangat sukses, dimana saat itu informasi mengalir tiada henti, dan untuk akses untuk mendapatkan informasi tersebut bisa digolongkan cukup mahal di Indonesia. Namun dengan BlackBerry semua masalah itu bisa terselesaikan dengan mudah.
Pertumbuhan pasar BlackBerry memang mengejutkan, khususnya setelah perangkat komunikasi ini dijual untuk konsumen umum (ritel / individual). Dalam tempo empat bulan setelah layanan BlackBerry On Demand diluncurkan Indosat jumlah pelanggan bertambah 15 ribu, dan angka ini yang cukup fantastis.

Saat ini target penjualan BlackBerry mencapai 100 ribu unit. Mungkinkah tercapai? Saat ini Pertumbuhan BlackBerry dari tahun ke tahun selalu tinggi. Kurun waktu tahun 2004 2005, pertumbuhannya $25 \%$. Tahun 2006 naik 50\%. Tahun $2006-2007$ tumbuh $100 \%$. Tahun $2007-2008$ berkembang $250 \%$. BlackBerry yang paling disukai saat ini adalah BlackBerry Curve 8520, BlackBerry Bold 9780, BlackBerry javelin 8900. Untuk harga, Harga BlackBerry Curve 8520 adalah harga BlackBerry yang digolongkan paling murah. Sehingga di tahun ini, peningkatan penjualan BlackBerry Gemini ini sangat pesat. 
Delphi 7.0 University Of Mitra

Indonesia. Retrieved From Osf.Io/Pbrn9.

\section{REFERENSI}

[1] A. S. Putra And O. M. Febriani, "Knowledge Management Online Application In Pdam Lampung Province," In Prosiding International Conference On Information Technology And Business (Icitb), 2018, Pp. 181-187.

[2] A. S. Putra, O. M. Febriani, And B. Bachry, "Implementasi Genetic Fuzzy System Untuk Mengidentifikasi Hasil Curian Kendaraan Bermotor Di Polda Lampung," J. Sist. Inf. Dan Manaj. Basis Data, Vol. 1, No. 1, Pp. 21-30, 2018.

[3] O. M. Febriani And A. S. Putra, "Sistem Informasi Monitoring Inventori Barang Pada Balai Riset Standardisasi Industri Bandar Lampung," J. Inform., Vol. 13, No. 1, Pp. 90-98, 2014.

[4] Putra, Arie Setya. "2018 Artikel Struktur Data, Audit Dan Jaringan Komputer." (2018).

[5] Putra, A. S. (2018, July 17). Paperplain Fundamental Create Application With Borland 